\title{
Bioanalytical Method Development and Validation for Herbal Quercetin in Nano Formulation by RP-UFLC in Rabbit Plasma
}

\section{Shanmugam $\mathbf{R}^{1 *}$, Gowthamarajan $\mathrm{K}^{1 *}$, Priyanka DL ${ }^{1}$, Madhuri $\mathrm{K}^{2}$ and Narayanareddy Karri VVS}

${ }^{1}$ Department of Pharmaceutics, JSS College of Pharmacy (A constituent college of JSS University, Mysore), Udhagamandalam, The Nilgiris, Tamilnadu, India ${ }^{2}$ Department of Pharmacology, JSS College of Pharmacy (A constituent college of JSS University, Mysore), Udhagamandalam, The Nilgiris, Tamilnadu, India

\begin{abstract}
A sensitive reverse phase ultra fast liquid chromatography (RP-UFLC) has been developed and validated for the quantification of Quercetin in nano formulation in rabbit plasma using solid phase extraction method (SPE). Best chromatographic resolution was achieved on a reverse phase Hibar ${ }^{\circledR} \mathrm{C}_{18}(250 \times 4.6 \mathrm{~mm}$ i.d., $5 \mu)$ column with the mobile phase consisted of acetonitrile: pottasium dihydrogen ortho phosphate $(\mathrm{pH} 3.5)$ in the ratio of $65: 35(\mathrm{v} / \mathrm{v})$ with a flow rate of $0.8 \mathrm{~mL} / \mathrm{min}$. The retention time for the drugs was found to be $8.6 \mathrm{~min}$ and $10.0 \mathrm{~min}$ for internal standard (fluticasone propionate). The analyte was detected by using a Photo-diode array (PDA) detector with LC solution software. Linearity was obtained in the concentration range of 10 to $400.0 \mathrm{ng} / \mathrm{mL}\left(r^{2}=0.989\right)$. Lower limit of quantification (LLOQ) was found to be $10 \mathrm{ng} / \mathrm{mL}$. Middle limit of quantification (MQC) was found to be $200 \mathrm{ng} / \mathrm{mL}$ and higher limit of quantification (HQC) was found to be $380 \mathrm{ng} / \mathrm{mL}$. The average recovery of the analyte was found to ranging from 95.91 to $98.59 \%$. The developed method isapplicablefor estimation of Quercetin in nano-formulation, routine quality control analysis, pharmacokinetic and bioequivalence studies.
\end{abstract}

Keywords: Quercetin; RP-UFLC; Rabbit plasma; Validation; Photo diode array detector; Pharmacokinetics; Nano-formulation

\section{Introduction}

Quercetin is a polyphenolic compound chemically it is

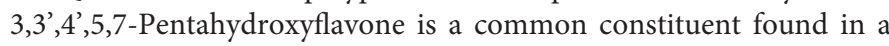
wide variety of fruits and vegetables [1]. Quercetin is attracting much of the researcher's attention due to its wide availability and potent biologically active agent for preventing various conditions such as for neoplastism [2], cardiovascular diseases [3], anti-inflammatory [4], bronchial hyper reactivity [5], and neurodegenerative disorders [6]. The mechanistic pathway in which it acts is mostly by direct radical scavenging of oxygen either in the free form or in the excited form.

Several studies were performed for estimation of the drug in various biological fluids by HPLC [7-19] but still these methods were not having proper chromatographic resolution where in some broad peak and the others the gap between the retention times of the drugs was not adequate. Though advanced methods such as LC-MS $[10,20,21]$ and LC-ES-MS [22] were also developed but still there is a gap in the normal labs where the drug estimation cannot be performed on sophisticated instruments hence a simple HPLC method is suitable for analysis.

The aim of the study was to develop simple, rapid and sensitive RP-UFLC method for the determination of Quercetin in rabbit plasma which is useful for the estimation of Quercetin in developed formulations, food product analysis, quality control, pharmacokinetics and bioequivalence profiling.

\section{Materials and Methods}

\section{Reagents and chemicals}

Quercetin standard (purity $>99 \%$ ), Acetonitrile of HPLC grade and all other chemicals for HPLC were purchased from S.D Fine Chem Ltd. (Mumbai, India). The chemicals required for the nano formulation were purchased from Rankem Ltd. (Mumbai, India).

\section{Instrumentation}

The UFLC system comprised of Shimadzu ultra fast liquid chromatography with a binary gradient pump of LC-20AD consisting of photodiode array detector(PDA) with a $20 \mu \mathrm{L}$ loop volume injection(Shimadzu, Japan) connected with LC solution software.

\section{Chromatographic conditions}

Chromatographic separation was achieved using $\mathrm{Hibar}^{\circ} \mathrm{C}_{18}$ $(250 \times 4.6 \mathrm{~mm}$ i.d., $5 \mu)$ stationary phase using a mobile phase of Acetonitrile: Phosphate buffer $\mathrm{pH} 3.5(65: 35, \mathrm{v} / \mathrm{v})$ at a flow rate of 0.8 $\mathrm{mL} / \mathrm{min}$. Quercetin was detected at $369 \mathrm{~nm}$ using a PDA detectorwith a retention time of $8.6 \mathrm{~min}$ and Fluticasone propionate as an internal standard with a retention time of 10.01 minutes.

\section{Statistical methods}

The standard calibration curves were fitted into a linear regression analysis and the graph was plotted for response factor against concentration of the standard solutions of drug and IS. The graph was used for estimating mean, standard deviation (SD) and percentage coefficient of variation (\% CV).

\section{Preparation of standard solution for plotting calibration curve}

Quercetin stock solutions were prepared freshly on each day

*Corresponding authors: Shanmugam R, Research Scholar, Department of Pharmaceutics, JSS College of Pharmacy, Rocklands, Udhgamandalam-643001, The Niligiris, Tamilnadu, India, Tel: +91-9843454943; Fax: 0423-2442937; E-mail: shanmugam_55555@yahoo.com

Gowtahmarajan K, Department of Pharmaceutics, JSS College of Pharmacy, Rocklands, Udhgamandalam-643001, The Niligiris, Tamilnadu, India, Tel: +919443089812; Fax: 0423-2442937; E-mail: gowthamsang@gmail.com

Received July 03, 2013; Accepted July 18, 2013; Published July 26, 2013

Citation: Shanmugam R, Gowthamarajan K, Priyanka DL, Madhuri K Narayanareddy Karri VVS (2013) Bioanalytical Method Development and Validation for Herbal Quercetin in Nano Formulation by RP-UFLC in Rabbit Plasma. J Bioequiv Availab 5: 191-196. doi:10.4172/jbb.1000157

Copyright: ( 2013 Shanmugam R, et al. This is an open-access article distributed under the terms of the Creative Commons Attribution License, which permits unrestricted use, distribution, and reproduction in any medium, provided the original author and source are credited. 
of analysis by dissolving $10 \mathrm{mg}$ of pure Quercetin in HPLC grade acetonitrile to make the volume up to $10 \mathrm{~mL}$. From the prepared stock solution serial dilutions in the range of $10-400 \mathrm{ng} / \mathrm{mL}$ were prepared and each solution was injected for about $20 \mu \mathrm{L}$ in sextuplicate and the method was validated for the various parameters such as accuracy, linearity, precision, limit of quantification and detection (LOD and LOQ). Internal standard used was also prepared in same method as that of the standard.

\section{Preparation of sample solution}

The Nano Formulation (NF) sample solution was prepared by accurately weighing $10 \mathrm{mg}$ of the NF and dissolved in HPLC grade acetonitrile, sonicated for 15 minutes, filtered and the volume was made up to $10 \mathrm{~mL}$ to obtain $1 \mathrm{mg} / \mathrm{mL}$ of solution keeping it as stock solution and further dilutions were prepared form the above prepared stock solution.

\section{Pharmacokinetic study design}

A single dose complete cross over method was employed for the study of Quercetin pharmacokinetics innanoformulation. Healthy male albino rabbits $(1.5-2.0 \mathrm{~kg})$ divided into three groups where group $1(n=3)$ received pure drug, group $2(n=3)$ received nano formulation and group $3(n=2)$ was considered as a control (administered with saline solution). Blood sample of about $0.5 \mathrm{ml}$ was withdrawn in heparinised tubes during different time points $(0,0.5,1,2,3,5,7,8,10,12$ and 24 hrs respectively) from the marginal ear vein of the rabbit. The collected samples were centrifuged at $4000 \mathrm{rpm}$ for 10 minutes and the plasma samples were stored at $-20^{\circ} \mathrm{C}$ until analysed. Pk software was used for calculating pharmacokinetic parameters.

\section{Method for determining linearity and accuracy}

Serial dilutions $(10-400 \mathrm{ng} / \mathrm{mL})$ of standard solutions were analysed and the peak areas were recorded and the standard concentrations were plotted against response factor. Regression line was recorded for each set of analysis where accuracy was determined by quantification of the standard solution in sextuplicate for the estimation of mean and $\%$ nominal.

\section{Method for determining precision, LOD and LOQ}

Precision of the study was calculated as per ICH guidelines (International Conference on Harmonization) (ICH, 2004) [23] for determination of intermediate precision and repeatability. Both inter and intraday repeatability wasestimated by injecting standard and sample solutions in sextuplicate and thereby mean and \% CV was calculated. Whereas LOD and LOQ were obtained by the formula

$\mathrm{LOD}=3.3 \sigma / \mathrm{m}$

$\mathrm{LOQ}=10 \sigma / \mathrm{m}$

Where $\sigma$ is the standard deviation of intercept of regression line and $\mathrm{m}$ is slope of calibration curve.

\section{Ruggedness}

Ruggedness of the developed method was assessed by checking the reproducibility and retention times of the standard and sample solutions. It was performed by analysing under variations in test conditions such as laboratory, analyst, reagents, different days and instruments.

\section{Preparation of plasma samples}

A $0.5 \mathrm{~mL}$ of the rabbit plasma samples were spiked with $0.5 \mathrm{~mL}$ of internal standard solution (400 $\mathrm{ng} / \mathrm{mL}$ ). The above solution was vortexed for 1-3 minutes and resulting solution was extracted with Solid Phase Extraction method (SPE). The drug was extracted from the solid phase extraction cartridge using $0.5 \mathrm{~mL}$ of acetonitrile and analysed in UFLC.

\section{Results and Discussion}

\section{Method development}

By studying various ratios of mobile phases, $\mathrm{pH}$, flow rate optimized chromatographic separation with a symmetric peak was obtained with a mobile phase of acetonitrile: phosphate buffer $\mathrm{pH} 3.5(65: 35 \mathrm{v} / \mathrm{v})$ at a flow rate of $0.8 \mathrm{~mL} / \mathrm{min}$ on a Hibar ${ }^{\circledR} \mathrm{C}_{18}$ column stationary phase. The method suitability was checked by the analysis of the sample in the spiked plasma and the retention time of the standard Quercetin was approximately 8.6 minutes (Figure 1) and no other peaks were observed at the same retention time of the standard drug.

\section{Specificity}

Specificity of the developed method shows good separation and no additional peak was observed near the drug retention time due to the endogenous materials. No endogenous substances were interfered with the detection of the drug. Representative typical chromatograph is shown in the Figure 1 and 2 .

\section{Linearity}

The linearity curve was plotted in the concentration range of $10-400 \mathrm{ng} / \mathrm{mL}$ and the calibration curve was found to be linear with a correlation coefficient of $r^{2}=0.9892$ which indicates a significant linear relationship among the amount and peak area in the tested range of concentration. There was not much variation in the inter day differences and in the standard deviation and standard error of slope values which indicates that the method was linear giving no scope for variation in the developed linearity curves and the results are given in the Figure 3 and Table 1.

Response factor against each concentration was calculated and each concentration was analysed in triplicate. The response factor was plotted in concentration range of $10-400 \mathrm{ng} / \mathrm{mL}$.

\section{Accuracy}

The method developed was found to be accurate, the \% nominal mean was found to be $95.91-98.59 \%$ which proves that the method was accurate. Table 2 indicates the \% CV, \% nominal and standard deviation of the standard curves of Quercetin.

\section{Precision}

Precision studies were carried out to check the inter day variation $(60,200$ and $400 \mathrm{ng} / \mathrm{mL})$ for intermediate precision studies and intraday precision $(60,200$ and $400 \mathrm{ng} / \mathrm{mL})$ for repeatability. The study was performed using a concentration range of $60-400 \mathrm{ng} / \mathrm{mL}$ where each concentration injected six times on three consecutive days. Mean and Relative Standard Deviations (RSD) were calculated and the low values of RSD indicate the method is precise and repeatable and the results are shown in Table 3 .

\section{LOD and LOQ}

LOD and LOQ are calculated as given in the above formula and found to be $5 \mathrm{ng} / \mathrm{mL}$ and $10 \mathrm{ng} / \mathrm{mL}$ respectively which are within $\pm 15 \%$ of accuracy and precision. These are achieved with a $20 \mu \mathrm{L}$ injection volume. 

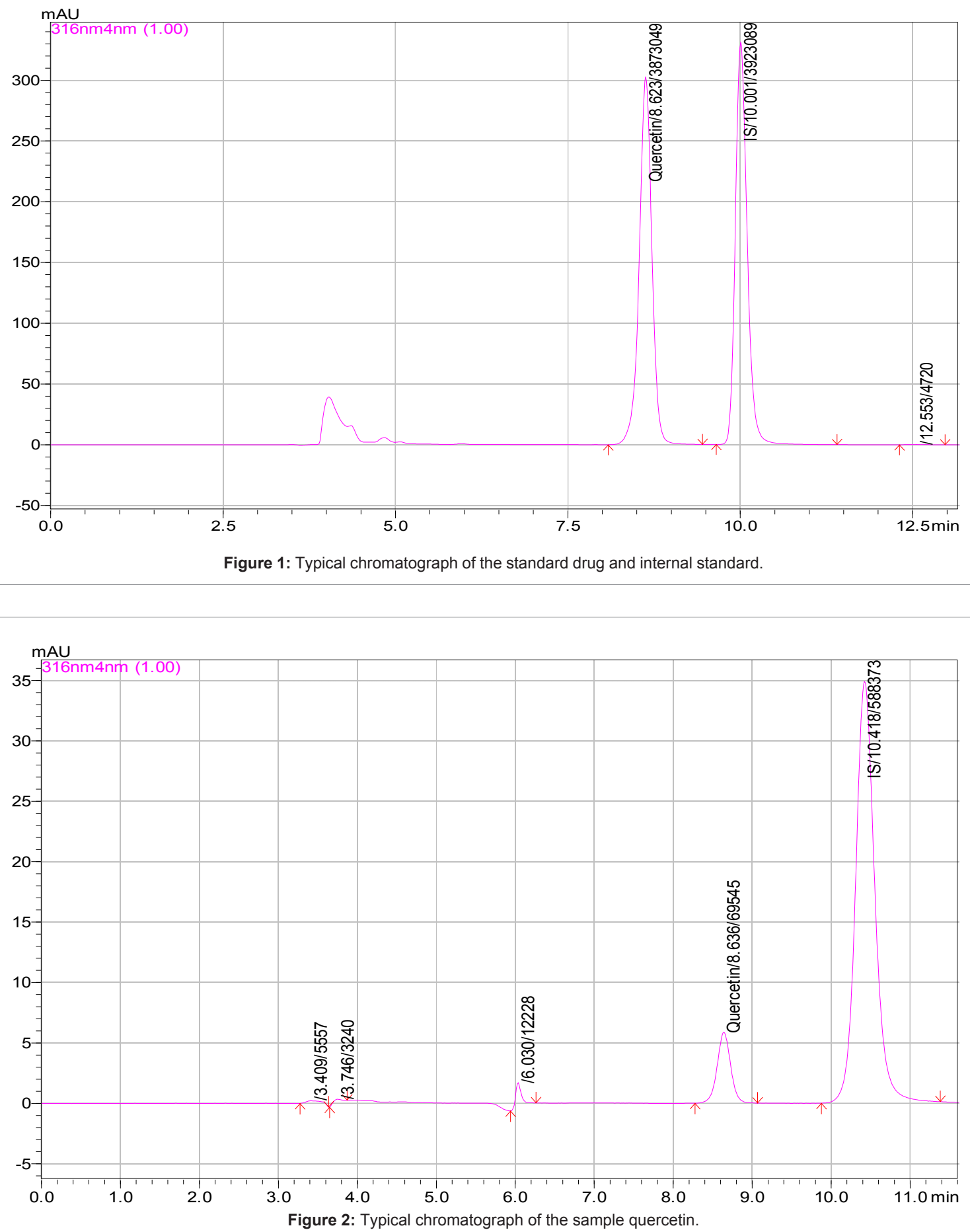

\section{Ruggedness}

Development of the method in various test conditions also led to the resolution at a retention time of 8.6 minutes for Quercetin which shows that the method is rugged.

\section{Recovery}

The mean recoveries of Quercetin at concentrations of $150 \mathrm{ng} / \mathrm{mL}$ $(n=6)$ were $95.82,97.57 \%$ respectively in the spiked rabbit plasma and the deviation of the study was within $15 \%$ of the limits and results are shown in the Table 2.

\section{Pharmacokinetic studies}

The concentration of Quercetin in rabbit's plasma was evaluated by UFLC method and the pharmacokinetic parameters were as given in Table 4 for both pure drug and nano formulation. The mean plasma concentration of the pure drug and the nano formulation were as shown in Figure 4. 
Citation: Shanmugam R, Gowthamarajan K, Priyanka DL, Madhuri K, Narayanareddy Karri VVS (2013) Bioanalytical Method Development and Validation for Herbal Quercetin in Nano Formulation by RP-UFLC in Rabbit Plasma. J Bioequiv Availab 5: 191-196. doi:10.4172/jbb.1000157

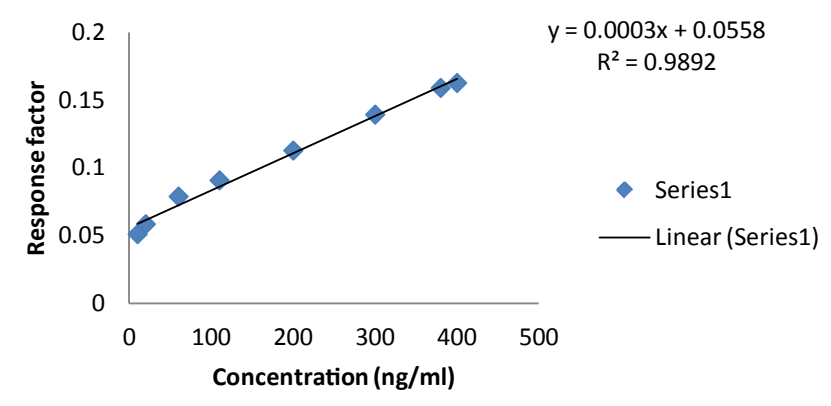

Figure 3: Calibration curve.

\begin{tabular}{|r|c|c|}
\hline S.NO & Concentration $(\mathbf{n g} / \mathbf{m L})$ & Response factor \\
\hline 1 & 10 & 0.050926 \\
\hline 2 & 20 & 0.058256 \\
\hline 3 & 60 & 0.078693 \\
\hline 4 & 110 & 0.090631 \\
\hline 5 & 200 & 0.112637 \\
\hline 6 & 300 & 0.139181 \\
\hline 7 & 380 & 0.158887 \\
\hline 8 & 400 & 0.162548 \\
\hline
\end{tabular}

Table 1: Concentration- Response factor for Quercetin.

\begin{tabular}{|c|c|c|c|c|}
\hline S.No & $\begin{array}{c}\text { Actual } \\
\text { concentration }(\mathbf{n g} / \\
\mathbf{m L})\end{array}$ & $\begin{array}{c}\text { Amount } \\
\text { spiked }(\mathbf{n g})\end{array}$ & $\begin{array}{c}\text { Measured } \\
\text { concentration } \\
\text { (ng/mL) }\end{array}$ & $\begin{array}{c}\text { \% Recovery } \\
\text { (mean } \mathbf{\text { SD}} \text { ) }\end{array}$ \\
\hline 1 & 200 & 150 & 147.89 & 98.59333 \\
\hline 2 & 200 & 150 & 145.64 & 97.09333 \\
\hline 3 & 200 & 150 & 146.81 & 97.87333 \\
\hline 4 & 200 & 150 & 148.13 & 98.75333 \\
\hline 5 & 200 & 150 & 145.83 & 97.22 \\
\hline 6 & 200 & 150 & 143.87 & 95.91333 \\
\hline Mean & & & 146.3617 & 97.57444 \\
\hline SD & & & 1.592211 & 1.061474 \\
\hline CV $(\%)$ & & & 1.087861 & 0.940476 \\
\hline
\end{tabular}

Table 2: Accuracy and recovery studies.

\begin{tabular}{|c|c|c|c|c|c|c|}
\hline \multirow{2}{*}{ S.No } & \multicolumn{3}{|c|}{ Interday studies } & \multicolumn{3}{|c|}{ Intraday studies } \\
\hline & $60(\mathrm{ng} / \mathrm{mL})$ & $200(\mathrm{ng} / \mathrm{mL})$ & $400(\mathrm{ng} / \mathrm{mL})$ & $60(\mathrm{ng} / \mathrm{mL})$ & $200(\mathrm{ng} / \mathrm{mL})$ & $400(\mathrm{ng} / \mathrm{mL})$ \\
\hline 1 & 4668 & 15563 & 31104 & 4742 & 15742 & 31523 \\
\hline 2 & 4683 & 15321 & 30984 & 4318 & 16732 & 31842 \\
\hline 3 & 4532 & 15832 & 30627 & 4261 & 15372 & 31537 \\
\hline 4 & 4583 & 15381 & 31832 & 4739 & 15731 & 31735 \\
\hline 5 & 4628 & 15931 & 30999 & 4783 & 15824 & 31934 \\
\hline 6 & 4599 & 15752 & 31873 & 4700 & 15732 & 31562 \\
\hline Mean & 4615.5 & 15630 & 31236.5 & 4590.5 & 15855.5 & 31688.8 \\
\hline SD & 56.159594 & 248.298 & 503.778 & 235.32 & 457.526 & 174.55 \\
\hline RSD & 1.21676078 & 1.5886 & 1.61279 & 5.12624 & 2.8856 & 0.55083 \\
\hline
\end{tabular}

Table 3: Precision studies. 
Citation: Shanmugam R, Gowthamarajan K, Priyanka DL, Madhuri K, Narayanareddy Karri VVS (2013) Bioanalytical Method Development and Validation for Herbal Quercetin in Nano Formulation by RP-UFLC in Rabbit Plasma. J Bioequiv Availab 5: 191-196. doi:10.4172/jbb.1000157

\begin{tabular}{|c|c|c|c|}
\hline \multirow[b]{2}{*}{ S.NO } & \multirow{2}{*}{$\begin{array}{l}\text { Time(hours) and } \\
\text { Pharmacokinetic } \\
\text { parameters }\end{array}$} & \multirow{2}{*}{$\begin{array}{l}\text { Nano } \\
\text { formulation } \\
\text { Concentration } \\
\text { (ng/mL) }\end{array}$} & \multirow{2}{*}{$\begin{array}{l}\text { Pure drug } \\
\text { Concentration } \\
\text { (ng/mL) }\end{array}$} \\
\hline & & & \\
\hline 1 & 0 & 0 & 0 \\
\hline 2 & 0.5 & 10.83635 & 9.54953 \\
\hline 3 & 1 & 22.85125 & 10.3611 \\
\hline 4 & 2 & 31.7934 & 15.07157 \\
\hline 5 & 3 & 83.7119 & 106.6077 \\
\hline 6 & 5 & 198.72836 & 125.37766 \\
\hline 7 & 7 & 236.41532 & 169.30415 \\
\hline 8 & 8 & 219.10241 & 195.4973 \\
\hline 9 & 10 & 159.83774 & 165.18968 \\
\hline 10 & 12 & 130.5835 & 120.38341 \\
\hline 11 & 18 & 124.9776 & 109.0875 \\
\hline 12 & 24 & 114.9085 & 98.0976 \\
\hline 13 & $\mathrm{C}_{\max }$ & 236.41532 & 195.4973 \\
\hline 14 & $\mathbf{T}_{\max }$ & 7 & 7 \\
\hline 15 & $A^{\prime} C_{0-t}$ & 3197.25176 & 2746.21701 \\
\hline 16 & keli $\left(\mathrm{h}-{ }^{-1}\right)$ & 0.03953183 & 0.03829696 \\
\hline 17 & $t_{1 / 2}(h)$ & 17.5339 & 18.0992749 \\
\hline 18 & AUC $_{o-\alpha}$ & 9177.63037 & 7850.99052 \\
\hline
\end{tabular}

Table 4: Individual plasma concentrations $(\mathrm{ng} / \mathrm{mL})$ and pharmacokinetic parameters for developed nano formulation and pure drug.

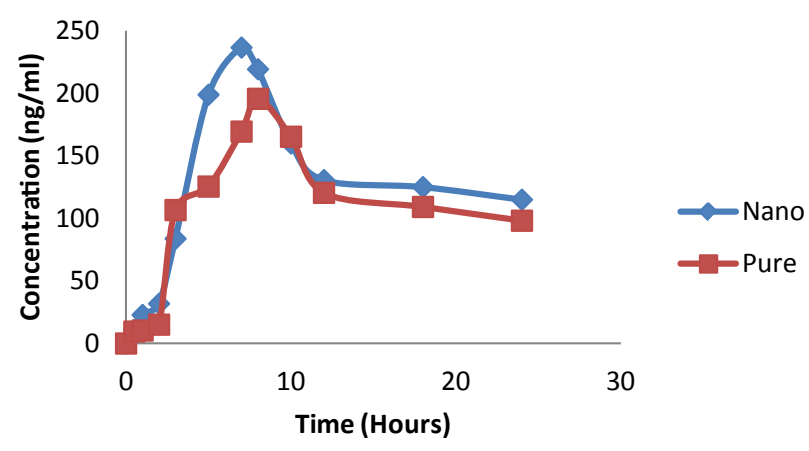

Figure 4: Mean plasma concentrations $(\mathrm{ng} / \mathrm{mL})$ curve.

Pharmacokinetic parameters were reported $\mathrm{C}_{\max }-$ Mean plasma concentration; $\mathrm{T}_{\max }-$ Mean time concentration; $\mathrm{AUC}_{0-\mathrm{t}, 0-\mathrm{a}}-$ Area under curve; $\mathrm{K}_{\mathrm{eli}}$ - Elimination constant; $\mathrm{t}_{1 / 2}$ - Half-life.

\section{Conclusion}

A validated reverse phase UFLC method was developed for the estimation of Quercetin in nano formulation in rabbit plasma. The method was simple, rapid, precise, accurate and rugged. The method finds its applicability in food product analysis, pharmacokinetics and bioequivalence profiling either as an individual component or in combination with other.

\section{Acknowledgements}

The authors are thankful to the management of JSS College of Pharmacy, Udhagamandalam for providing necessary facilities to complete the research work.

\section{References}

1. Hertog MGL, Hollman PCH, Katan MB, Kromhout D (1993) Intake of potentially anticarcinogenic flavonoids and their determinants in adults in The Netherlands. Nutr Cancer 20: 21-29.

2. Murakami A, Ashida H, Terao J (2008) Multitargeted cancer prevention by quercetin. Cancer Lett 269: 315-325.

3. Kamada C, Da Silva EL, Ohnishi-Kameyama M, Moon JH, Terao J (2005) Attenuation of lipid peroxidation and hyperlipidemia by quercetin glucoside in the aorta of high-cholesterol-fed rabbit. Free Radic Res 39: 185-194.

4. Cho SY, Park SJ, Kwon MJ, Jeong TS, Bok SH, et al. (2003) Quercetin suppresses proinflammatory cytokines production through MAP kinesis and NF-kappa B pathway in lipopolysaccharide-stimulated macrophage. Mol CellBiochem 243:153-160.

5. Dorsch W, Bittinger M, Kaas A, Müller A, Kreher B, et al. (1992) Antiasthmatic effects of Galphimia glauca, gallic acid, and related compounds prevent allergen- and platelet-activating factor-induced bronchial obstruction as well as bronchial hyperreactivity in guinea pigs. Int Arch Allergy Appl Immunol 97:1-7.

6. Youdim KA, Shukitt-Hale B, Joseph JA (2004) Flavonoids and the brain interactions at the blood-brain barrier and their physiological effects on the central nervous system. Free Radic Biol Med 37: 1683-1693.

7. Fan D, Zhou $X$, Zhao $C$, Chen $H$, Zhao $Y$, et al. (2011) Anti-inflammatory, antiviral and quantitative estimation of Quercetin-3-O- $\beta$-D-glucuronide in Polygonum perfoliatum L. Fitoterapia 82: 805-810.

8. Hasler A, Sticher O, Meier B (1992) Identification and determination of the flavonoids from Ginko biloba by high-performance liquid chromatography. $J$ Chromatogr A 605: 41-48.

9. Chin L, Rong LY, Yu HC, Ching WK (2000) Evaluation of quantitative analysis of flavonoid aglycones in Gingko biloba extract and its products. JFDA8: 289296.

10. Brolis M, Gabetta B, Fuzzati N, Pace R, Panzeri F et al. (1998) Identification by high-performance liquid chromatography-diode array detection-mass spectrometry and quantification by high-performance liquid chromatographyUV absorbance detection of active constituents of Hypercium perforatum. J Chromatogr A 825: 9-16.

11. Careri M, Elviri L, Mangia A, Musci M (2000) Spectrophotometric and coulometric detection in the high - performance liquid chromatography of flavonoids and optimization of sample treatment for the determination of Quercetin in orange juice. J Chromatogr A 881: 449-460.

12. Escarpa A, Gonzalez MC (2000) Optimization strategy and validation of one chromatographic method as approach to determine the phenolic compounds from different sources.J Chromatogr A897: 161-170.

13. Schieber A, Keller P, Carle R (2001) Determination of phenolic acids and flavonoids of apple and pear by high-performance liquid chromatography. $J$ Chromatogr A 910: 265-273.

14. Merken HM, Beecher GR (2000) Liquid chromatographic method for the separation and quantification of prominent flavonoid aglycones. J Chromatogr A897: 177-184.

15. Erlund I, Alfthan G, Siren H, Ariniemi K, Aro A (1999) Validated method for the quantification of Quercetin from human plasma using high-performance liquid chromatography with electrochemical detection. J Chromatogr B 727: 179-189.

16. Morrice PC, Wood SG, Duthie GG (2000) High performance liquid chromatographic determination of Quercetin and isohamnetin in rat tissues using $\beta$-glucuronidase and acid hydrolysis.J Chromatogr B 738: 413-417.

17. Li W, Fitzloff JF (2002) HPLC determination of flavonoids and terpene lactones in commercial Gingko biloba products. J Liq Chromatogr Relat Techno 25 2501-2514.

18. Crozier A, Jensen E, Lean MEJ, McDonald MS (1997) Quantitative analysis of flavonoids by reversed-phase high-performance liquid chromatography. $J$ Chromatogr A761: 315-321.

19. Shanmugam R, Gowthamarajan K, Priyanka DL, Madhuri K, Hemnath E, et al. (2013) Development and Validation of a RP- UFLC Method for Simultaneous Estimation of Quercetin and Rutin. Hygeia J D M 5: 113-120.

20. He XG (2000) On-line identification of phytochemical constituents in botanical extracts by combined high-performance liquid chromatographic-diode array detection-mass spectrometric techniques. J Chromatogr A880: 203-232. 
Citation: Shanmugam R, Gowthamarajan K, Priyanka DL, Madhuri K, Narayanareddy Karri VVS (2013) Bioanalytical Method Development and Validation for Herbal Quercetin in Nano Formulation by RP-UFLC in Rabbit Plasma. J Bioequiv Availab 5: 191-196. doi:10.4172/jbb.1000157

21. Andlauer W, Martena MJ, Furst P (1999) Determination of selected phytochemicals by reversed-phase high-performance liquid chromatography combined with ultraviolet and mass spectrometric detection. J Chromatogr A849: 341-348.

22. Ndjoko K, Wolfender JL, Hostettmann K (2000) Determination of trace amounts of ginkgolic acids in Ginkgo biloba L. leaf extracts and Phytopharmaceuticals by liquid chromatography-electrospray mass spectrometry.J Chromatogr B 744: 249-255.

23. Food and Drug Administration (1996) International Conference on Harmonisation: guidance on Q2(R1) validation of analytical procedures: text and methodology. Fed Regist 62: FR 27464. 